\title{
Decision making using a combination of management accounting and an expert approach
}

\author{
Dmitry V. Isaev \\ Associate Professor, Department of Business Analytics \\ National Research University Higher School of Economics \\ Address: 20, Myasnitskaya Street, Moscow, 101000, Russian Federation \\ E-mail:disaev@hse.ru
}

Abstract

This paper focuses on the questions of combining management accounting and an expert approach for decision making in the sphere of economics and management. The background of such a combination is that within both approaches there are a decision making goal, a set of alternatives and criteria for their assessment, as well as the possibility of multivariate evaluation of the alternatives for different possible situations.

The basic decision making processes provide similar data processing. Their scope relies on classification of assessment criteria into three types: quantitative criteria, for which source information for management accounting is available, quantitative criteria with lack of source information for management accounting, and qualitative criteria, for which management accounting methods are not applicable. Relying on such classification, four basic processes are defined: pure management accounting, management accounting supplemented by estimates according to predefined rules, management accounting supplemented by expert estimates, and the pure expert approach.

Relying on different basic processes, fifteen working processes (including the generalized working process including all four basic processes) are defined. Conclusions are made regarding the practical applicability of different working processes, depending on the scope of decision making criteria.

Approval of the combined approach is performed with the help of an example of investment appraisal relating to a manufacturing company's development, using three classic management accounting criteria (payback period, net present value, internal rate of return), and three criteria of a qualitative nature.

Key words: decision making, management accounting, expert approach, assessment of alternatives, investment appraisal, analytic hierarchy process.

Citation: Isaev D.V. (2016) Decision making using a combination of management accounting and an expert approach. Business Informatics, no. 4 (38), pp. 70-78. DOI: 10.17323/1998-0663.2016.4.70.78.

\section{Introduction}

$\mathrm{M}$ odern business often faces various decision making tasks - selecting one of alternative courses of action. One of the approaches to decision making is management accounting, which deals with the collection, processing and presentation of relevant financial and economic information. Classic examples of decision making using management accounting are the selection of activity level and product mix, decisions regarding stopping production 
or replacing some products, "make or buy" decisions, justification of further processing of joint products, as well as investment appraisals [1-3].

An important feature of management accounting is that it deals with financial and economic calculations which allow us to compare alternatives from the point of view of costs and economic benefits. However, under conditions of incompleteness and unreliability of source information, as well as in cases when qualitative or semi-structured information is essential, management accounting becomes inapplicable.

Another way of decision making is the expert approach, which involves one or few experts who evaluate alternatives according to certain criteria, relying on their knowledge, experience and management intuition. In the case of group decision making, special coefficients representing differences in the experts' competences may be applied. Forming expert estimates and their further processing may be performed by various decision making methods, such as the analytic hierarchy process and the analytic network process [4-6], methods of the ELECTRE family [7], methods of the PROMETHEE family [8-10] and some others. Processing of expert estimates often requires quite complex mathematical calculations, so there is a special class of information systems - decision support systems [11].

Both approaches are widely represented in academic and business literature, and successfully applied in practice. However, the two approaches are always considered separately. At the same time, quite often multicriteria decision making tasks arise, where for some criteria management accounting is applicable, while for other criteria only the expert approach may be used. That is why there a question arises about the possibility of combining management accounting and the expert approach within common decision making processes.

\section{Decision making using the management accounting and expert approaches: Similarities and differences}

For answering the question about the possibility of combining the management accounting and an expert approach an analysis of their similarities and differences is essential. It is reasonable to conduct such an analysis on the basis of various aspects, such as objectives of the approaches and their areas of use, source information ant its origin, methods of assessing alternatives and the degree of their objectivity, the number of criteria, and the possibility of multivariate (situational) analysis.
As already noted, the objective of both approaches is evaluation of alternatives and selecting one of them as the most preferable. While management accounting is applicable only in the field of economics and management, the expert approach has a much wider area of use: it may be used in very different fields of human activity, including education, medicine, ecology, and politics.

Regarding source information, management accounting deals with quantitative (first of all, financial) information, which is well structured. Such information may come from multiple internal and external sources - the accounting systems of an enterprise, corporate reporting of an enterprise and external organizations, statistical databases, analytical reviews, etc. Management accounting information is quite reliable; however, in the case of lack or insufficient source data reliability estimated values may be used.

Within the expert approach, any relevant information including qualitative and semi-structured information may be used. Sources of such information may be very different, being situated either inside or outside an enterprise. The scope of information for the expert approach may be much wider than the scope of information for management accounting. Some information may be known to certain experts, but unknown to other experts and moderators of the assessment. In addition, when evaluating an alternative, each expert may use his personal tacit knowledge, experience, vision and intuition.

From the point of view of the ways of evaluating alternatives, management accounting uses the results of calculations, expressed in financial an economic terms. The expert approach deals with expert estimates, which may be expressed in different scales (scoring, ordinal), or via preferences in some other form (for example, the analytic hierarchy process includes pairwise comparisons based on the verbal-numerical fundamental scale).

Management accounting aspires to the best possible objectivity, so rough values are applied only in rare cases, when objective information is not available or is not reliable enough. As to the expert approach, it is initially oriented to collection and consolidation of the subjective opinions of experts, with additional analysis of concordance of such estimates.

Regarding the number of criteria, most management accounting tasks deal with a single criterion. For example, selection of the activity level uses such a criterion as the relation between marginal profit and fixed costs, product mix selection - marginal profit per unit of limiting factor, justification of discontinuing or replacing 
products - the difference between price and production cost, etc. However, in some cases several criteria may be used, but without generalizing the results obtained for different criteria. For example, for investment appraisal such criteria as accounting rate of return, payback period, net present value or internal rate of return are applicable.

Within the expert approach, either one, or several criteria may be used (in the latter case there is a multicriteria decision making task [12]). If criteria have different significance, special weights may be assigned to them. In all cases, in multicriteria tasks formal rules of generalizing expert estimates by criteria are applied.

From the point of view of situational analysis, management accounting makes possible multivariate calculations, depending on decision making situations (first of all, the projected state of the external environment) and, accordingly, relying on different source data sets. However, no formal rules for generalizing results by situations are considered within management accounting.

The expert approach also permits one to consider different situations, but with the use of formal rules for generalizing the results. The probabilities of occurrence may be assigned to situations (directly or by ranking), or one may consider that decision is to be made under uncertainty.

So, both management accounting and the expert approach imply the availability of some set of alternatives and criteria for their assessment that arise from the decision making goal. Both approaches also permit multivariate assessment of the alternatives, depending on possible situations. Such common features of management accounting and the expert approach may be considered as a background for their combination within decision making processes. At the same time, there are such specific features of the expert approach as availability of experts, as well as evaluating alternatives in abstract terms, rather than using financial and economic measures. In turn, these particularities lead to differences in methods of generalizing estimates by experts, criteria and situations.

\section{Combining the management accounting and expert approaches: Basic and working decision making processes}

Decision making processes may be subdivided into basic and working processes. Within basic processes, source information is processed similarly, while within working processes source information may be processed in different ways. Working processes are defined relying on the basic ones: each working process may be equal to one of the basic processes, or include a combination of some of them.

Any decision making process (both basic and working) starts with a conceptual statement of a decision making task (goal, alternatives, criteria, etc.) and ends with final consideration of the results obtained (as a rule, in the forms of discussions or meetings, with the participation of all the stakeholders) and the final decision making.

Definition of the basic processes relies on classification of criteria used for assessing alternatives. First of all, criteria are subdivided into quantitative and qualitative. In addition, for quantitative criteria source information for management accounting calculations may be either available, or not. Thus, the criteria may be subdivided into three types:

1. Quantitative criteria for which source information for management accounting calculations is available;

2. Quantitative criteria for which source information for management accounting calculations is not available;

3. Qualitative criteria for which management accounting methods are inapplicable.

Assessment of the alternatives with respect to criteria of types 2 and 3 may be executed only using the expert approach. As to criteria of type 1, it is possible to apply management accounting calculations, and in addition their results may become the subject of a subsequent expert assessment.

Classification of criteria allows us to determine four basic processes:

BP 1 - pure management accounting. After the conceptual statement of a task, one selects the relevant management accounting method, then the appropriate source information is collected. The results of management accounting calculations become the basis for ranking the alternatives and are presented for final consideration and decision making without any additional expert assessment. Such a basic process is applicable for the criteria of type 1 ;

$\checkmark$ BP 2 - management accounting supplemented by rules-based estimates. After the conceptual statement of a task, selecting the relevant management accounting method and collecting appropriate source information, the calculations are performed. Then the results of management accounting calculations are transformed into estimates according to predefined rules, without any additional expertise. Since the transformation rules are determined in an expert way (although a priori, regardless 
of the management accounting results), such estimates, in fact, also arise from the expert approach. On this basis, ranking the alternatives, and then - final consideration and decision making are executed. This basic process is also applicable for the criteria of type 1;

^ BP 3 - management accounting supplemented by expert estimates. After the conceptual statement, selecting the management accounting method and collecting appropriate source information, the calculations are executed. The results of management accounting calculations are subject to additional expert assessment. Then the expert estimates become involved in subsequent calculations using one of decision making methods. After this, ranking of alternatives, final consideration and decision making are executed. Like BP 1 and BP 2, this basic process is applicable for the criteria of type 1;

$\downarrow$ BP 4 - the pure expert approach. After the conceptual statement, a decision making method is selected and expert estimates are formed. The results of processing the expert estimates are used for ranking the alternatives, then final consideration and decision making are performed. This basic process is applicable for the criteria of types 2 and 3 (theoretically, BP 4 may also be applied for criteria of the type 1 , but this would mean loss of potentially valuable management accounting information, so this variant is not considered).

The estimates used within the basic processes may be either expert-based, or rules-based. The difference is that expert estimates are formed by experts (perhaps, taking into consideration management accounting results), while rules-based estimates are formed directly by transforming management accounting results according to predefined rules, without additional expertise. In fact, the basic processes BP 2 and BP 3 are quite close: both include management accounting calculations and subsequent forming of estimates; the difference is that estimates in BP 2 are rules-based, while BP 3 applies expert estimates.

Ultimately, estimates (expert-based or rules-based) are applied within the basic processes BP 2, BP 3 and BP 4, however expert assessment of alternatives takes place only in BP 3 and BP 4. As to management accounting, it is used in the basic processes BP 1, BP 2 and BP 3 .

In some cases it seems reasonable to use management accounting and the expert approach separately, in their pure forms. Application of pure management accounting (BP 1) is reasonable if there is a single criterion which belongs to type 1 (in this case synthesis of criteria is not required, so additional estimates are excessive). The pure expert approach (BP 4) should be used if all the criteria belong to types 2 and 3 . In the rest of cases, it seems reasonable to combine the management accounting and expert approaches in one or another way.

Working processes, unlike the basic processes, assume the availability of both quantitative and qualitative criteria, as well as processing of information for different criteria in different ways. This means that few basic processes may be combined within the same working process.

Let us consider the most common case, where criteria of all three types are available, and where management accounting results obtained for different criteria of type 1 are used in different ways: for some criteria - in pure form, for others - as a basis for transformation into rules-based estimates, for third cases - as source information for expert estimates. Such a case requires the use of all four basic processes; the appropriate generalized working process is presented in Figure 1.

The working processes relating to particular cases represent different variations of the generalized decision making process. Each of such variations includes a specific set of basic processes (Table 1).

The applicability of the working processes depends on the nature of the criteria involved in decision making tasks:

$\diamond$ working processes WP $1-$ WP 7 are applied if some criteria belong to type 1 , while the rest of the criteria to types 2 and/or 3 (including tasks with criteria of all three types). In this case, at least one of the processes BP 1 - BP 3 (in any combination) and BP 4 are used. If there are criteria of all three types, the working process WP 1 is equal to the generalized process;

$\diamond$ working processes WP 8 - WP 14 are applied if all criteria belong to type 1 . In this case the process WP 4 is not used, only processes BP 1 - BP 3 are applied (separately or in any combination). The working processes WP 8, WP 9 and WP 10 are equal to the basic processes BP 1 (pure management accounting), BP 2 and BP 3 accordingly;

$\diamond$ working process WP 15 is applied if all criteria belong to types 2 and/or 3 . This working process is equal to the basic process BP 4 (the pure expert approach).

It should be noticed that if BP 1 is not used then estimates (either rules-based or expert- based) are formed for all the criteria, with their subsequent processing. If BP 1 is applied, then the task is split into two parts: for some criteria no estimates are applied (management accounting results are used directly in the stage of final consideration and decision making), while with respect to other criteria estimates are formed, with their further processing. 


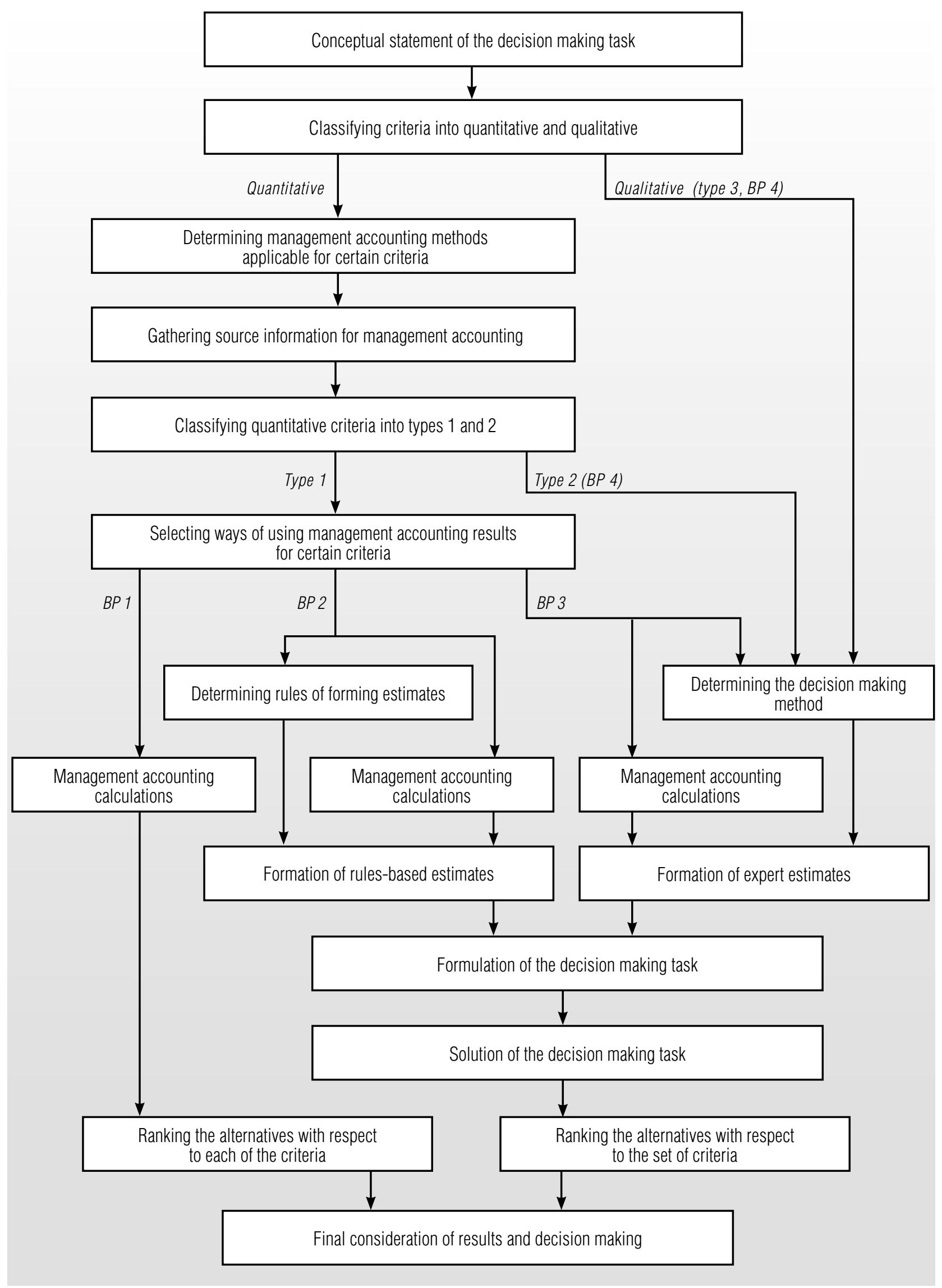

Fig. 1. Generalized working decision making process 
Table 1. $-C_{4}-$ impact of the new product on the enterprise's

Working decision making processes

\begin{tabular}{|c|c|c|c|c|}
\hline \multirow{2}{*}{$\begin{array}{l}\text { Working } \\
\text { processes }\end{array}$} & \multicolumn{4}{|c|}{ Basic processes } \\
\hline & BP 1 & BP 2 & BP 3 & BP 4 \\
\hline WP 1 & + & + & + & + \\
\hline WP 2 & + & - & - & + \\
\hline WP 3 & - & + & - & + \\
\hline WP 4 & - & - & + & + \\
\hline WP 5 & + & + & - & + \\
\hline WP 6 & + & - & + & + \\
\hline WP 7 & - & + & + & + \\
\hline WP 8 & + & - & - & - \\
\hline WP 9 & - & + & - & - \\
\hline WP 10 & - & - & + & - \\
\hline WP 11 & + & + & - & - \\
\hline WP 12 & + & - & + & - \\
\hline WP 13 & - & + & + & - \\
\hline WP 14 & + & + & + & - \\
\hline WP 15 & - & - & - & + \\
\hline
\end{tabular}

\section{Example: Investment appraisal}

As an example, let us consider one of the classical management accounting tasks - investment appraisal.

A manufacturing company examines a few variants of its business development through construction of a new plant and introduction of a new product. This project has an investment nature: it implies initial capital expenditures and subsequent long-term economic benefits. There are three alternatives (variants of development) $X_{1}, X_{2}$ and $X_{3}$. Each of the alternatives are evaluated with respect to six criteria:

- $C_{1}$ - payback period;

- $C_{2}$ - net present value (NPV);

- $C_{3}$ - internal rate of return (IRR); reputation (qualitative, technological, ecological and social matters);

- $C_{5}$ - reliability of operations (risks related to the new product manufacturing and sales, including potential lack of quality and dependence on key suppliers and customers);

- $C_{6}$ - prospects of the new product (possibility of long-term business development).

The criteria $C_{1}, C_{2}$ and $C_{3}$ are quantitative, and the company has all the information required for management accounting. So, these three criteria belong to type 1 and for them management accounting calculations are to be performed. Meanwhile, the decision maker assumes that payback period figures are sufficient for final consideration, while interpreting net present value and internal rate of return requires additional expert assessment - to justify the significance of differences between the figures obtained for different alternatives. This means that with respect to criterion $C_{1}$ the basic process $\mathrm{BP} 1$, and for criteria $C_{2}$ and $C_{3}$ - the basic process BP 3 are used.

As to criteria $C_{4}, C_{5}$ and $C_{6}$, they all are qualitative and belong to type 3 , so for them only the basic process BP 4 is applicable.

Thus, for comparison of the variants of the company's development and final decision making the working process WP 6 involving the basic processes BP 1, BP 3 and BP 4 is to be applied.

As a decision making method for generalizing estimates with respect to criteria $C_{2}-C_{6}$, an analytic hierarchy process (AHP) [4-6] is used. Eventually, the information presented for final consideration consists of payback period figures for the different alternatives (criterion $C_{1}$ ) and the alternatives' priorities determined with respect to criteria $C_{2}-C_{6}$ using the AHP method.

The results of management accounting for the different alternatives with respect to criteria $C_{1}-C_{3}$ are presented in Table 2. As we see in the table, the best value of payback period is related with the alternative $X_{3}$, the best value of net present value - with the alternative $X_{1}$, and the best value of internal rate of return - with the alternative $X_{2}$. The payback period figures are to be presented for final consideration "as is", without any additional assessment. As to the remaining two criteria, their figures are to be used as additional information for forming expert estimates. 
Table 2. ing the analytic hierarchy process method, taking into

Results of management accounting calculations for criteria $C_{1}-C_{3}$

\begin{tabular}{c|c|c|c}
\hline $\begin{array}{c}\text { Alterna- } \\
\text { tives }\end{array}$ & $\begin{array}{c}\text { Payback } \\
\text { period } \\
\left(C_{\mathbf{1}}, \text { years }\right)\end{array}$ & $\begin{array}{c}\text { Net present } \\
\text { value } \\
\left(C_{2}, \text { mln. rubles }\right)\end{array}$ & $\begin{array}{c}\text { Internal rate } \\
\text { of return } \\
\left(C_{3}, \%\right)\end{array}$ \\
\hline $\boldsymbol{X}_{\mathbf{1}}$ & 5.5 & 250.2 & 16.6 \\
\hline $\boldsymbol{X}_{\mathbf{2}}$ & 4.5 & 230.4 & 17.2 \\
\hline $\boldsymbol{X}_{\mathbf{3}}$ & 4.0 & 196.1 & 13.7 \\
\hline
\end{tabular}

The analytic hierarchy process method as a tool for generalizing of expert estimates implies constructing a hierarchical structure "goal-criteria-alternatives" and subsequent pairwise comparison of the elements in each level with respect to the upper level elements. In our case, there are six pairwise comparison sessions: one for comparing criteria with respect to the goal, and five for comparing the alternatives with respect to each of the decision making criteria $\left(C_{2}-C_{6}\right)$.

The results of each session are entered into a pairwise comparison matrix. In any of such matrices, rows and columns represent the compared elements, while the intersections contain their comparative estimates expressed in terms of the verbal-numerical fundamental scale (Saaty's scale). Relying on the estimates, priorities of elements in the lowest hierarchical level (alternatives) with respect to the highest level element(the goal) are calculated ${ }^{1}$.

The pairwise comparison matrix of the criteria and their priorities with respect to the goal are shown in the Table 3, and the pairwise comparison matrix of the alternatives with respect to criteria $C_{2}$ - in the Table 4 (the alternatives' comparison with respect to other criteria is performed similarly). Based on priorities of the criteria with respect to the goal and priorities of the alternatives with respect to each of the criteria, synthesizing overall priorities is executed (Table 5). By applying the working process WP 6 , the following results are subject to final consideration and decision making (Table 6):

$\checkmark$ the values of payback period (criterion $C_{1}$ ) for each of the alternatives determined using management accounting;

$\downarrow$ overall priorities of the alternatives with respect to the remaining five criteria $\left(C_{2}-C_{6}\right)$, determined us- consideration the management accounting results for criteria $C_{2}$ and $C_{3}$.

Table 3.

Pairwise comparison matrix and priorities of the criteria $C_{2}-C_{6}$ with respect to the goal

\begin{tabular}{|c|c|c|c|c|c|c}
\hline \multirow{2}{*}{ Griteria } & \multicolumn{5}{|c|}{ Griteria } & \multirow{2}{*}{ Priorities } \\
\cline { 2 - 6 } & $C_{2}$ & $C_{3}$ & $C_{4}$ & $C_{5}$ & $C_{6}$ & \\
\hline$C_{2}$ & 1 & 2 & 3 & 4 & 4 & $\mathbf{0 . 4 1 4}$ \\
\hline $\boldsymbol{C}_{\mathbf{3}}$ & $1 / 2$ & 1 & 2 & 3 & 3 & $\mathbf{0 . 2 5 7}$ \\
\hline $\boldsymbol{C}_{\mathbf{4}}$ & $1 / 3$ & $1 / 2$ & 1 & 2 & 2 & $\mathbf{0 . 1 5 3}$ \\
\hline $\boldsymbol{C}_{\mathbf{5}}$ & $1 / 4$ & $1 / 3$ & $1 / 2$ & 1 & 1 & $\mathbf{0 . 0 8 8}$ \\
\hline $\boldsymbol{C}_{\mathbf{6}}$ & $1 / 4$ & $1 / 3$ & $1 / 2$ & 1 & 1 & $\mathbf{0 . 0 8 8}$ \\
\hline
\end{tabular}

Table 4.

Pairwise comparison matrix and priorities of the alternatives with respect to the criterion $C_{2}$ (net present value)

\begin{tabular}{c|c|c|c|c}
\hline \multirow{2}{*}{$\begin{array}{c}\text { Alterna- } \\
\text { tives }\end{array}$} & \multicolumn{3}{|c|}{ Alternatives } & \multirow{2}{*}{ Priorities } \\
\cline { 2 - 5 } & $X_{1}$ & $X_{2}$ & $X_{3}$ & \\
\hline$X_{1}$ & 1 & 2 & 6 & $\mathbf{0 . 6 0 0}$ \\
\hline$X_{2}$ & $1 / 2$ & 1 & 3 & $\mathbf{0 . 3 0 0}$ \\
\hline$X_{3}$ & $1 / 6$ & $1 / 3$ & 1 & $\mathbf{0 . 1 0 0}$ \\
\hline
\end{tabular}

Table 5.

Synthesizing to obtain overall priorities

\begin{tabular}{|c|c|c|c|c|c|c}
\hline \multirow{2}{*}{$\begin{array}{c}\text { Alterna- } \\
\text { tives }\end{array}$} & \multicolumn{5}{|c|}{ Griteria and their weights } & \multirow{2}{*}{$\begin{array}{c}\text { Overall } \\
C_{2} \\
\text { priorities }\end{array}$} \\
\cline { 2 - 6 } & $C_{3}$ & $C_{4}$ & $C_{5}$ & $C_{5}$ \\
$(0.257)$ & $(0.153)$ & $(0.088)$ & $(0.088)$ & \\
\hline$X_{1}$ & 0.600 & 0.300 & 0.090 & 0.455 & 0.143 & 0.392 \\
\hline$X_{\mathbf{2}}$ & 0.300 & 0.600 & 0.455 & 0.090 & 0.143 & 0.369 \\
\hline $\boldsymbol{X}_{\mathbf{3}}$ & 0.100 & 0.100 & 0.455 & 0.455 & 0.714 & 0.239 \\
\hline
\end{tabular}

${ }^{1}$ All the calculations are performed using Super Decisions software (www.superdecisions.com) 
Results presented for final consideration and decision making

\begin{tabular}{c|c|c}
$\begin{array}{c}\text { Alter- } \\
\text { natives }\end{array}$ & $\begin{array}{c}\text { Payback period } \\
\text { (eriterion } C_{1} \text {, years) }\end{array}$ & $\begin{array}{c}\text { Estimate with respect } \\
\text { to eriteria } C_{2}-C_{6} \\
\text { (overall priorities) }\end{array}$ \\
\hline $\boldsymbol{X}_{\mathbf{1}}$ & 5.5 & 0.392 \\
\hline $\boldsymbol{X}_{\mathbf{2}}$ & 4.5 & 0.369 \\
\hline $\boldsymbol{X}_{\mathbf{3}}$ & 4.0 & 0.239 \\
\hline
\end{tabular}

As can be seen from the table, when interpreting the results, the decision maker has to make an informal choice, because none of the alternatives has the advantage over the others. Such a situation is typical for all the working processes in which the basic process BP 1 is combined with at least one of the remaining basic processes. In such cases, justification may rely on some additional information about possible variants, as well as on the decision maker's opinion regarding the significance of differences in results obtained for different alternatives.

\section{Conclusion}

Management accounting and expert assessment are two approaches which may be combined for decision making in the field of economics and management.
There are three ways to use the results of management accounting calculations.

First, management accounting results may be considered directly, at the final stage of the decision making process, in parallel with the results of processing of rules-based and expert estimates. In this case, the results of financial and economic calculations (using one or another management accounting method) and the results of estimates processing (using one or another decision making method) are presented for final consideration independently from each other.

Secondly, management accounting results may be used as a background for forming estimates relying on predefined rules (rules-based estimates), without any additional expert assessment. Such estimates are subsequently processed using one of the decision making methods.

Thirdly, management accounting results may be delivered to experts as source information which may be taken into consideration during the formation of expert estimates. Such estimates are also processed using one of the decision making methods.

Different ways of combining the management accounting and expert approaches may be used within the same task but with respect to different criteria. It is also possible to arrange multivariate calculations, where management accounting results for the same criteria are used in different ways depending on the situations under consideration. All this expands the analytical capability and creates a background for more justifiable decision making.

\section{References}

1. Drury C. (2015) Management and cost accounting. London: Cengage Learning EMEA.

2. Atrill P., McLaney E. (2015) Management accounting for decision makers. Harlow, UK: Pearson.

3. Kovalev V.V. (2015) Finansovyy menedzhment: teoriya i praktika [Financial management: theory and practice]. Moscow: Prospect (in Russian).

4. Saaty T.L. (2008) Decision making with the analytic hierarchy process. International Journal of Services Sciences, vol. 1, no. 1, pp. 8398.

5. Saaty T.L., Peniwati K. (2008) Group decision making: Drawing out and reconciling differences. Pittsburgh: RWS Publications.

6. Saaty T.L. (2015) Prinyatie resheniy pri zavisimostyakh i obratnykh svyazyakh: Analiticheskie seti [Decision making with dependence and feedback: The analytic network process]. Moscow: LENAND (in Russian).

7. Roy B. (1991) The outranking approach and the foundation of ELECTRE methods. Theory and Decision, no. 31, pp. 49-73.

8. Brans J.P., Vincke Ph. (1985) A preference ranking organization method. Management Science, no. 31, pp. 647-656.

9. Brans J.P., Vincke Ph., Marechal B. (1986) How to select and how to rank projects: The PROMETHEE method. European Journal of Operational Research, no. 24, pp. 228-238.

10. Brans J.P., Marechal B. (1994) The PROMCALC \& GAIA decision support system for multicriteria decision aid. Decision Support Systems, no. 12, pp. 297-310.

11. Kravchenko T.K. (2010) Ekspertnaya sistema podderzhki prinyatiya resheniy [Expert decision support system]. Open Education, no. 6, pp. 147-156 (in Russian).

12. Figueira J., Greco S., Ehrgott M., eds. (2005) Multiple criteria decision analysis: State of the art surveys. Boston, MA: Springer. 


\title{
Принятие решений на основе сочетания управленческого учета и экспертного подхода
}

\author{
Д.В. Исаев \\ кандидат экономических наук, доцент кафедры бизнес-аналитики \\ Национальный исследовательский университет «Высшая школа экономики» \\ Адрес: 101000, г. Москва, ул. Мясницкая, д. 20 \\ E-mail:disaev@hse.ru
}

\begin{abstract}
Аннотация
В статье рассматриваются вопросы сочетания управленческого учета и экспертного подхода при принятии решений в сфере экономики и менеджмента. Предпосылками такого сочетания является то, что оба подхода предполагают наличие некоторого множества альтернатив и критериев их оценки, вытекающих из цели принятия решения, а также возможность многовариантной оценки альтернатив, в зависимости от рассматриваемых ситуаций.

Базовые процессы принятия решений, предусматривающие однотипную обработку информации, основаны на классификации критериев принятия решений на три типа: количественные критерии, для которых имеется исходная информация для применения управленческого учета, количественные критерии, для которых такая информация отсутствует, и качественные критерии, для которых методы управленческого учета неприменимы. На основе классификации критериев выделены четыре базовых процесса: применение управленческого учета в чистом виде, применение управленческого учета с последующим оцениванием альтернатив по предопределенным правилам, применение управленческого учета с последующей экспертизой и формированием экспертных оценок, применение экспертного подхода в чистом виде.

На основе различных сочетаний базовых процессов выделены пятнадцать рабочих процессов принятия решений, включая обобщенный рабочий процесс, предусматривающий применение всех четырех базовых процессов. Сделаны выводы о практической применимости отдельных рабочих процессов, в зависимости от состава критериев, имеющих место в задачах принятия решений.

Апробация предложенного подхода выполнена на примере задачи обоснования инвестиций в развитие производственной компании, с применением трех классических критериев инвестиционного анализа (период окупаемости, чистая приведенная стоимость, внутренняя норма рентабельности) и трех критериев качественного характера.
\end{abstract}

Ключевые слова: принятие решений, управленческий учет, экспертный подход, оценка альтернатив, инвестиционный анализ, метод анализа иерархий.

Цитирование: Isaev D.V. Decision making using a combination of management accounting and an expert approach // Business Informatics. 2016. No. 4 (38). P. 70-78. DOI: 10.17323/1998-0663.2016.4.70.78.

\section{Литература}

1. Drury C. Management and cost accounting. London: Cengage Learning EMEA, 2015.

2. Atrill P., McLaney E. Management accounting for decision makers. Harlow, UK: Pearson, 2015.

3. Ковалев В.В. Финансовый менеджмент: теория и практика. М.: Проспект, 2015.

4. Saaty T.L. Decision making with the analytic hierarchy process // International Journal of Services Sciences. 2008. Vol. 1. No. 1. P. 83-98.

5. Saaty T.L., Peniwati K. Group decision making: Drawing out and reconciling differences. Pittsburgh: RWS Publications, 2008.

6. Саати Т.Л. Принятие решений при зависимостях и обратных связях: Аналитические сети. М.: ЛЕНАНД, 2015.

7. Roy B. The outranking approach and the foundation of ELECTRE methods // Theory and Decision. 1991. No. 31. P. 49-73.

8. Brans J.P., Vincke Ph. A preference ranking organization method // Management Science. 1985. No. 31. P. 647-656.

9. Brans J.P., Vincke Ph., Marechal B. How to select and how to rank projects: The PROMETHEE method // European Journal of Operational Research. 1986. No. 24. P. 228-238.

10. Brans J.P., Marechal B. The PROMCALC \& GAIA decision support system for multicriteria decision aid // Decision Support Systems. 1994. No. 12. P. 297-310.

11. Кравченко Т.К. Экспертная система поддержки принятия решений // Открытое образование. 2010. № 6. - С. 147-156.

12. Multiple criteria decision analysis: State of the art surveys / Edited by J. Figueira, S. Greco, M. Ehrgott. Boston, MA: Springer, 2005. 